\title{
Life and Death In \\ Diary Of A Mad Old Man By Junichiro Tanizaki, Aku By Chairil Anwar, The Jilting Of Granny Weatherall By Kathrene Anne Porter And The Tinkers By Paul Harding
}

\author{
Yanti Rahayuningsih , Arlisa Indriawati \\ Corresponding author Yanti (yan sada@yahoo.com \\ Universitas Teknologi Surabaya
}

\begin{abstract}
Even every work of arts especially in literature has unique story style yet also has similarities in the idea or problems of a human being. The similarities appear in their works because they share some common aspects of life which are also called the intertextuality. Themes and motives in the work of arts are similar because of the universal consciousness among the authors. And by these works Diary of a Mad Old Man by Junichiro Tanizaki, Aku by Chairil Anwar, The Jilting of Granny Weatherall by Kathrene Anne Porter and The Tinkers by Paul Harding deals with the same theme about life and death. The analysis is using qualitative method to evaluate the similarities and the differences concept of life and death from four above. From the analysis, it is found out that there is correlation of each work related with the intertextuality among them. Even from the analysis, there are 6 difference aspects regarding their perception in adjusting their death but also proving that four text voices the similar notion, about human reaction depicted when they are confronted by death.
\end{abstract}

Keywords: intertextuality, life and death's themes

\section{Introduction}

Every piece of reality in this world about some other piece of reality. Literature as the highest expression of human life can't be separated from reality. Furthermore, Tailor stated that literature like other parts is essentially an imaginative act, that is, an act of writer imagination that presents information and value as work of art, but is not only to entertain, but also to give the readers information and valuable experiences about human life. The prominent theme about human life is related to life and death which becomes the ultimate journey of every human. Death is an inescapable fact of life that touches everyone sometimes.

Throughout history we have seen evidence of man's obsession with mortality. The idea that everything has an end has been considered. To understand the unknown, humans often come up with stories and poetry that give them an explanation of what they can grasp. The problem with this way of dealing with impermanence is that it often shows just how insecure and un-accepting of these unavoidable changes we can be. Literature often can show just how vulnerable humans can be and yet somehow managing to find elegant, beautiful and dignified ways to show it. Four examples of these written masterpieces are 
Diary of a Mad Old Man by Junichiro Tanizaki, Aku by Chairil Anwar, The Jilting of Granny Weatherall by Kathrene Anne Porter and The Tinkers by Paul Harding deal with the same theme about life and death. Moreover, three main characters also in the same age, they are old people who fought their lives before death took it away

Literature is a media to explore human lives which are communicated by each author by using their unique writing style. In spite of each author's characteristic, they sometimes tell the same ideas or problems of human being. The similarities appear in their works because they share some common aspects of life. It also called the intertextuality as stated by the Roland Barthes "Every text, being itself the intertext of another text," and Umberto Eco her book, The Name of the Rose, intertextuality is an inevitable condition of textuality. Books speak of other books, and stories tell what has already been told. Themes and motives in the work of arts are similar because of the universal consciousness among the authors, and four works above also told about the human point of view toward death. Some old people may not experience a great deal of fear about death but no one has a neutral attitude toward it. It is virtually impossible for old person can't avoid the question of their death. There are simply too many reminders of our eventual fate as we grow old. Thus by analyze each work above, we can gradually grasp the similarities and the concept of the differences of life and death and also to be able to find out any correlation of each work-related with the intertextuality among them. There some aspect in death and life as motive which is prevalent in four works above, they are Self-esteem, Death Anxiety, Guilty, Life Optimism, Wholeness and Incompleteness. Based on those aspects the writes tried to examine the differences or similarities from the works related with death and life as a prominent motive in those 6 novels.

\section{Methodology}

This analysis completely focused on life and death theme in 4 works, Diary of a Mad Old Man by Junichiro Tanizaki, Aku by Chairil Anwar, The Jilting of Granny Weatherall by Kathrene Anne Porter and The Tinkers by Paul Harding. Because of the tool in this analysis is intertextuality then by using it we can know about the stream unconsciousness of the authors. Intertextuality refers to the interdependent ways in which texts stand in relation to one another (as well as to the culture at large) to produce meaning. They can influence each other, be derivative of, parody, reference, quote, contrast with, build on, draw from, or even inspire each other. Knowledge does not exist in a vacuum, and neither does literature.

As Kristeva wrote, any text can be considered a work of intertextuality because it builds on the structures that existed before it. There are countless examples of authors borrowing from the Bible and from Shakespeare, from titles (William Faulkner's Go Down, Moses and The Sound and the Fury) to story lines (John Steinbeck's East of Eden and Jane Smiley's A Thousand Acres). A single novel or poem can never be considered independent of the system of meanings in which it relays its message; indeed, each new work of literature transforms and displaces discourse which predated it.

Authors are influenced cumulatively by what they've read, whether or not they explicitly show their influences on their characters' sleeves. Sometimes they do want to draw parallels between their work and an inspirational work or influential canon-think fan fiction or homages. Maybe they want to create emphasis or contrast or add layers of meaning through an allusion. In so many ways literature can be interconnected intertextually, on purpose or not. In this analysis, 4 authors Junichiro Tanizaki, Chairil Anwar, Kathrene Anne Porter and Paul Harding describing their characters with the same 
nuance in life and death theme. By using qualitative method to evaluate and describe their Self-esteem, Death Anxiety, Guilty, Life Optimism, Wholeness and Incompleteness, the writer tried to find the intertextuality among them.

\section{Diary of a Mad Old Man by Junichiro Tanizaki}

Diary of mad old man, written by Junichiro Takizaki is a story of an old man by the name Tokusuke Utsugi who is told as a lunatic old man, which is set in $20^{\text {th }}$ century where Japan is still struggling with the effect of World War II. Utsugi, like another of Tanizaki's characters, driven by obsessive erotic desires. This aged diarist is struck down by neuralgia, which brought by an excess of sexual excitement. Unfortunately, at that time he is infatuated with his daughter in law which made his condition worse. Despite his awareness of his condition and death that comes on his way, Utsugi is lost in his sexual desire. By the end he is captivated in his image and unable to sense his real self.

Formerly, Utsugi realizes that he has dark personalities which mostly triggered by his obsessive thought toward beauty. He appreciates and even felt attract with something aesthetic, in the woman and also in man. Because of that, he disgraces toward his old hideous appearance. He felt that his ugliness made his life pathetic. Furthermore he tried to search for another beauty in another person, in this case in his daughter in law, Satsuko, to make his life more meaningful and peaceful. Those feelings showed that Utsugi tried to maintain his self-esteem by the search for beauty in his life.

Related with his opinion toward death, he seems unafraid and ready to embrace the afterlife. He even regularly visualizes the condition when he finally died. He enjoyed the dream what his family will do about it. On page 17 , when he heard that he had a crucial decease, he almost felt relieved, because he thought that his long life finally coming to an end. Even though, he believes his attraction to the opposite sex would last until he died, but he hasn't the slightest desire to cling to life.

Ironically, even he seems already prepare and ready to lose his life, Utsugi as a normal human, also having death-anxiety. It showed when he felt ultimate pleasure after licking Satsuko's feet, “...long as I had been prepared for death, the thought of 'dying' frightened me..."(Tanizaki: 68). Also when his grandson, Keisuke, suddenly showed affection for him, he hardly able controlled his emotion. As a cold-hearted, violent and perverse man, Utsugi's nature not allowed him to showed weak emotion, fear, and loses control toward anything, death also. But on page 118, he realizes that he can't escape from his fate, his aged body, his weakened soul and incoming death made him change.

His feeling toward Satsuko, his daughter in law, actually is the main conflict between his life instinct and death impulse. It's like two sides of coin, when he thinks of Satsuko, he felt like gambling on the slightest chance to live again but when he looks at satsuko, when she treated him like a tiresome invalid, made him want to die right away. Because of that, when he wants Satsuko's feet in his future grave personified his worship. His adoration resembles with the human love for their God. Utsugi thinks he will find peace if he rest his body and soul under the power of God. Even though he believe in Buddha, he prefers Satsuko, because he believed and felt attract to her and hopes that he would remain forever inside of her. 


\section{$A k u$ by Chairil Anwar}

'Aku' becomes one of memorable poetry in Indonesia. Even though, Chairil creates it in the middle of Dutch's colonization, around 1943, the spirit is still enchanted every reader's souls. This poem enlighten a man courage, even he has suffered from anything, like danger, poison, obstacles, and even death, he will stand straight and keep forward. From the first verse, the speaker understand that death is inevitable fate, the utmost stage in human's journey, because of that he acknowledge the power of death and ready to embrace it. So thus, he doesn't want anyone pity his destiny, not even his beloved. He wants if the death comes in his front door, anyone or anything won't block his grip on his door handle, slowed his step, or made him hide. No, he won't life as a coward.

Although, in the next verse, the speaker admitted that he was not a good man. As 'binatang jalang', human symbolization, he might be not educated, alienated, weird, and unusual, not socialize person, and life lonely but he is a strong man. And even he hindered by human's obstacles and unlucky destiny, his wound will not suppress his life spirit. The speaker believes time will heal anything, every wound he suffered over and over will be made him less suffer, and so, that's why the speaker said "Aku mau hidup seribu tahun lagi"... He will endure any pains, because, without it, human life is boring, stagnant, and meaningless. The speaker thinks, each wound, pain, loss, happiness, sorrow, love, hatred, etc., will carve the human soul beautifully. Then if death takes the soul away, it can be said, I love to be alive.

\section{The Jilting of Granny Weatherall by Kathrene Anne Porter}

This unique short story, tells the last moments of an old woman's long hard struggle through life. Porter examines the mind of Granny Weatherall describing the key moments of her life that influenced her outlook. Her life was not only a struggle against the emotional and physical obstacles to survival, but also a struggle to define herself and her purpose in life. Porter presents the disillusionment and meaninglessness associated with modern thought through the failure of Granny Weatherall to find and fulfill a purpose in her life.

Granny's abandonment by those she loved in her life creates the psychological need for her to control in order to have purpose in her life. Lying on her deathbed, she contemplates that "...she found dead in her mind and it felt clammy and unfamiliar. She had spent so much time preparing for death ..." (Porter: 2). Even though she thought she made her peace with death once already, in the end she realized that this was not so and her last thoughts are one of a very confused elderly lady. Even though, she did become physically stronger and weathered by the sun as she took up quite a few manual duties such as fencing in acreage and sitting up with sick people and animals.

When she had a fever in her sixties, it was then she was prepared to accept death, but it never came. This death coming now has caught her by surprise and grief. Surprise because it seems sudden and she had made plans for tomorrow, all little things that needed to be done and now would not be at all. (Since she does not believe her children can get by in life without her.) Grief because that once "again no bridegroom and the priest in the house". Before she slips away and dies, Granny thinks she is facing the ultimate loss, the loss of God Himself, as her internal monologue indicates: "... God, give me a sign! For a second time 
there was no sign. Again no bridegroom and the priest in the house. She could not remember any other sorrow because this grief wiped them all away. Oh, no, there's nothing crueler than this-I'll never forgives it..." (Porter: 8). It has seen that even though Granny weathered by all her loss, in the end, because her loss, her sorrow, her pain, she unable to believe anything, she has unfair prejudice toward herself, God seems to leave her side. She flew alone without anything to hold, it such bitter fate for her. So that's why, she said with typical impudence "I'll never forgive it."

\section{The Tinkers by Paul Harding}

"Tinkers" is a complex elegiac meditation on the insubstantiality of human life. A dying man witnesses the collapse of his personality structure and with that his obscure ties to those with whom he has shared the experiences of a lifetime. To convey the unfathomable substance of life, Harding uses a cacophony of voices, stylistic techniques, and writing styles, as if to suggest that the examined life is nothing short of ponderous and unsatisfying. The beauty of nature and knowledge of the workings of things are all man can hope to fill his hungry heart. To seek beyond that limited understanding is absurd. Thus was George Washington Crosby's vocation as a high school mechanical drawing teacher and guidance counselor apropos for a man who intuitively recognized life's limitations.

Harding's use of the apple image becomes apparent in the middle of the novel in which George is sitting on the couch reading. This is significant because this is when George starts to realize that his father is a lunatic because he bit George's hand during his seizure and George knows that his father will probably be sent off to a mental institution. The apple exemplifies the fact that George is starting to realize his father is a madman. This foreshadows the same struggle that George may face in the future. George later ponders about running away himself just like his father. He thinks that even his brother Joe "...would be sent to the madhouse too, sooner or later..." (Harding, Ch. 2). The apple foreshadows that later on, George follows his father's footsteps and runs away. Because the apple serves not only as a symbol but foreshadows events to happen, whenever Harding uses the apple in the story, the struggle is presented.

In terms of characterization, one might argue that all three men: Howard, his father, and George, are self-absorbed, meditative loners whose bewilderment with the world might be rooted in their inabilities to connect with people. Most disturbing is the fact that the people with whom George shares his last days and moments are ghostly presences, only one of them seemingly a companion on that final lap to unconsciousness. This person is, of course, his deceased father, a tinker, who first exposed the young and confused George to the grandeur of the natural world. One might argue with George's death bed glimpses into the hollowness of life. Perhaps had he committed his time to others - deeply and profoundly - he might have left the world differently, perhaps in the warm cocoon of humans loving him and wishing him well through the awaiting journey.

Time as the motif, George as a clockmaker, is a man who obsessed with keeping time. His life is measured in very definite time as well; throughout the novel, what happens is framed by how long George has to live. Harding compares human life to the intricate workings of a clock. They are reliable, complex machines that can be put to careful use, but they cannot make life anything other than absurd. Both Howard and George can distinguish the blending of light and dark in the landscapes of their lives, but neither can perceive any 
truth that lies beyond their mere struggles to survive. Both are consoled by the beauty of the physical world, but like Howard's father who dies in an insane asylum, both men realize the impossibility of fathoming meaning beyond the physical world. It seems that building a bird's nest or repairing a clock cannot fill the gaps created by a loveless marriage or open up for a despairing woman. The short moments of feeling connected to nature cannot explain why a father would abandon his children or a woman would commit her husband to an institution. Howard's father, a minister, is so baffled by his inability to grasp the meaning of life that he goes crazy. As a result of his father's insanity, Howard engages in a lifelong search for meaning, tinkering his way among people in a hopeless quest for meaning. However, nothing changes; nothing gets any better.

At one point Howard notes that a clock or "The universe's time cannot be marked. Such a crooked and flimsy device could only keep the fantastic hours of unruly ghosts. "And so it is that as George transitions into the netherworld he experiences a "shifting mass, the tiles of a mosaic spinning, swirling, portraying, always in recognizable swaths of colors, familiar elements, molecular units, intimate currents, showing him a different self every time he tried to make an assessment." And although "George never permitted himself to imagine his father," he finds their lives inextricably bound by doing the same conventional, simple activities of the living being. Because life is hard and needs an explanation, he also forgave his mother, even though her actions break up the marriage of his parents and separated him from his father. George realized that she was simply unable to rise above her despair. It is the existential lot of all humans.

For Howard, the pictures of angels in the family bible mean fear; for George, his intuitive leanings are not gifts of faith, but it's opposite, more depicted in his final hallucinations of the collapse of his house, the house being the classic Jungian metaphor of the personality structure. Likewise, Harding implies the transcendental elements when a man dies, like Bryant's "Thanatopsis": George realizes "the dark tablets of my death" will be a "scrolling" which will move about and be "mingled within endless ways of other people's memories. Man is part of the whole of nature "back to Adam". George also notes: that although the "mystery" of life is man's to think about, the condition of life itself is a "puzzle" that never quite fits together. And Howard further notes, "And when you resent the ache in your heart, remember: You will be dead and buried soon enough." Life is a struggle; make the most of it by "blending with the elements."

\section{Conclusion}

Four works of art above are beautiful tales depicted a simple while a complicated matter of human life and death. Utsugi, the speaker in 'Aku', Granny Weatherall and George Washington Crosby are some examples of how the human would react if death appears in their life. By analyzing it, we can gradually grasp the similarities and the differences concept of life and death which defined from Self-esteem, Death Anxiety, Guilty, Life Optimism, Wholeness and Incompleteness theme inside the story 
Differences:

\begin{tabular}{|l|l|l|l|l|}
\cline { 2 - 5 } \multicolumn{1}{c|}{} & $\begin{array}{l}\text { Diary of a Mad } \\
\text { Old Man }\end{array}$ & Aku & $\begin{array}{l}\text { The Jilting of } \\
\text { Granny Weatherall }\end{array}$ & The Tinkers \\
\hline Self-esteem & $\sqrt{ }$ & $\sqrt{ }$ & - & - \\
\hline Death Anxiety & $\sqrt{ }$ & - & $\sqrt{ }$ & - \\
\hline Guilty & - & - & $\sqrt{ }$ & $\sqrt{ }$ \\
\hline Life Optimism & - & $\sqrt{ }$ & - & - \\
\hline Wholeness & $\sqrt{ }$ & $\sqrt{ }$ & - & $\sqrt{ }$ \\
\hline Incompleteness & - & - & $\sqrt{ }$ & - \\
\hline
\end{tabular}

Death is the end of one's life. Adjustment to death indicates the personal adjustment of each person to the inevitability of death. Some human action is taken to ignore or avoid the inevitability of death. The terror of absolute annihilation creates such anxiety in people that they spend their lives attempting to make sense of it. Moreover, people commonly think of themselves as beings of value and worth, a concept in psychology known as self-esteem, that somewhat resolves the realization that people may be no more important than any other living thing. Self-esteem is used as a buffer for people to help them cope with anxiety; it defenses mechanisms to control their terror, along with realizing that humans are animals just trying to manage the universe around them. Four main characters have a different perception of adjusting their deaths. Even most of them stated that they are prepared their final time, but actually there are some aspects which made them different, and it's related with how they valued their life.

\section{The similarities:}

As stated previously, there are similarities among texts, which related to intertextuality. Intertextuality forms one of the crucial grounds for writing studies and writing practice. Texts do not appear in isolation, but concerning other texts. As stated by Allen, intertextuality reminds us that all texts are potentially plural, reversible, open to the reader's presuppositions, lacking in clear and defined boundaries, and always involved in the expression or repression of the dialogic 'voices' which exist within society (Allen, 2000:209).

"... I dreaded so much as premonition of death, but now that is no longer true...yet, haven't I been saying I don't care when I die..." (Tanizaki: 17 \& 121)

“Kalau sampai waktuku, 'Ku mau tak seorang 'kan merayu” (Chairil)

"...she found death in her mind and it felt clammy and unfamiliar. She had spent so much time preparing for death there was no need for bringing it up again. Let it take care of itself now..." (Porter: 2)

"... The quilt of leaves and light and shadow and ruffling breezes might part and I'd be given a glimpse of what is on the other side" (Harding: 54) and also 
in "... looked like the end of the road was...Howard feel as if he were walking through a kaleidoscope...dropped leaves and spear of grass and wildflowers and tree branches into the blueness and, as it rolled back down toward its proper place, ...it turning in hushed and peaceful exchange..." (Harding: 142)

From four quotations and previous analysis, it is shown that there is similar notion, an intertextuality, about how humans will react when their life confronted by death. It is natural as a human to always facing the death at any time. Although, on the certain stages, fearing it is also human automatic characteristic but human eventually will came to the stage of acceptance. They realizes that their life is priceless because it has a limit. The dreadfulness and the holiness are precious too. Therefore, eventually they learn to enjoy ther life and death.

Both differences and similarities previously exemplified that the four works even having different authors, cultural background and time setting, they have same notion of life and death. Because it is described that "life" is not just "stop," but "simply ends." Life is best summed up: "The ache in your heart and the confusion in your soul means that you are still alive, still human, and still open to the beauty of the world, even though you have done nothing to deserve it." In the end, according to Harding, we are all tinkers, tinkering away at life, plumbing some of its complex mechanics, such as the inner workings of a clock. After all, it is man's self-reliance that equips him both to acknowledge and accept the limitations of being human. By using aspects, Self-esteem, Death Anxiety, Guilty, Life Optimism, Wholeness and Incompleteness, it is proved that there some intertextuality between them.

\section{REFERENCES}

Allen, Graham (2000) Intertextuality New Fetter Lane, London: Routledge.

Anwar, Chairil. Kumpulan Puisi-puisi Chairil Anwar (pdf)

Eco, Umberto. 1983. The name of the rose. Boston: Houghton Mifflin Harcourt

Harding, Paul. 2011. The Thinkers. London: Windmill Books

Porter, Katherine Anne. 1930. The Jilting of Granny Weatherall (pdf)

Kristeva, Julia. 1980. Desire in Language: A Semiotic Approach to Literature and Arts. New York: Colombia University Press

Tanizaki, Junichiro. 1965. Diary of a Mad Old Man. New York: Alfred A. Knopf, Inc. http://crimealwayspays.blogspot.com/2010/07/nobody-move-this-is-review-tinkers-by.html http://www.helium.com/items/2198239-psychological-and-physicall-turning-point-grannyweatherall-katherine-anne-porter

http://tomakeamends.wordpress.com/2007/09/04/idolatry-guilt-vs-self-destruction-33/

Clugston, R. W. (2010). Journey into literature. San Diego, California: Bridgepoint Education, Inc. https://content.ashford.edu/books

http://www.wikipedia.com/items/2198239/death-adjustment-self-esteem-anxiety/45 
Acuity (4) 2, 204-213

http://www.medpedia.com/news_analysis/89-Literature-Arts-and-Medicineblog/entries/92152-Humanity-Out-of-Context-Tinkers-as-a-Touchstone-forDissection 